\title{
Effects of dietary beef tallow on performance, rumen fermentation, carcass traits and meat quality of growing lambs
}

\author{
S. López-Aguirre ${ }^{1,2}$, J.M. Pinos-Rodríguez ${ }^{2 \#}$, J.G. Vicente $^{2}$, H. Lee Rangel ${ }^{1}$, A. de la Cruz ${ }^{1}$ \& \\ I.A. Domínguez-Vara ${ }^{3}$ \\ ${ }^{1}$ Facultad de Agronomía y Veterinaria, Universidad Autónoma de San Luis Potosí, 78000, S.L.P. México \\ ${ }^{2}$ Facultad de Medicina Veterinaria y Zootecnia, Universidad Veracruzana, 91710, Veracruz, México \\ ${ }^{3}$ Facultad de Medicina Veterinaria y Zootecnia, Universidad Autónoma del Estado de México, 50090, México
}

(Received 21 February 2019; Accepted 22 November 2019; First published online 19 January 2020)

Copyright resides with the authors in terms of the Creative Commons Attribution 4.0 South African Licence.
See: http://creativecommons.org/licenses/by/4.0/za
Condition of use: The user may copy, distribute, transmit and adapt the work, but must recognise the authors and the South African
Journal of Animal Science.

\begin{abstract}
Growing lambs were evaluated for the effect of increasing dietary levels of beef tallow (BT) on performance, rumen fermentation, and carcass and meat characteristics. Twenty-one 5-month-old male Rambouillet lambs were assigned randomly to one of three diets with 0,20 , and $40 \mathrm{~g} \mathrm{BT} / \mathrm{kg}$ dry matter (DM) and similar energy and protein contents. Lambs were adapted to the diets for 15 days, followed by a 45-day evaluation trial. Data were analysed using a mixed model. Growth, feed intake and ruminal fermentation were not affected by the dietary level of BT. Daily metabolizable energy intake (MEI), carcass yield and degree of fatness, increased linearly as the BT level increased. Carcass classification and muscle conformation were not affected by BT. Most meat characteristics (texture, $\mathrm{pH}$, myoglobin, protein content, colour, cathepsins, and chemical composition) five and eight days post-mortem were not affected, except for fat content in meat, which increased linearly as diet BT level increased. Fatty acid (FA) profiles of the meat from lambs fed the three diets were similar. In conclusion, addition of BT at 20 and $40 \mathrm{~g} / \mathrm{kg} \mathrm{DM}$ to diets for growing lambs allowed reduced grain usage and increased forage levels (from 0 to $270 \mathrm{~g} / \mathrm{kg} \mathrm{DM}$ ), increasing energy intake, carcass yield and fatness, and intramuscular fat without causing harmful effects on growth, feed intake or ruminal fermentation characteristics.
\end{abstract}

Keywords: dietary fat, fatty acids, meat colour, sheep

\#Corresponding author: jpinos@uv.mx

\section{Introduction}

The proportion of grain in diets for finishing lambs has increased considerably. However, empirical evidence of potentially harmful effects of grain-based diets on rumen fermentation, feed intake, growth, and meat characteristics is still limited. Interestingly, the average growth rate of fattening lambs in Latin American countries is lower compared with the levels of performance that are achieved in North America, Europe, Asia, and Oceania. Although this can be explained from environmental, cultural and economic perspectives; nutritional limitations are also evident (Pinos, 2010). Fat can be used to increase dietary energy density and to increase the absorption of fat-soluble nutrients and reduce dust from the diet (NRC, 2001). Use of fat supplementation to increase dietary energy density and improve efficiency of milk production in dairy cattle is supported in the recent review of Palmquist and Jenkins (2017) and the meta-analysis of Weld and Armentano (2017). Tallow, yellow grease and mixtures are traditionally used as common sources of fat for beef cattle (Guerrero et al., 2016). For beef cattle, supplemental oils that protect from rumen biohydrogenation modify muscle FA profiles while leaving growth performance unaffected (Scollan et al., 2007). Several studies show that dietary lipids from vegetable oil in sheep generally do not affect growth rate, but lambs supplemented with linseed and sunflower oil show improvements in feed efficiency (Howes et al., 2014; Van Cleef et al., 2016). Most studies on dairy cows, beef steers and sheep have used oilseeds or ruminally inert fats. There is extremely limited work, however, on the impact of using free oil and tallow. In sheep, two studies have evaluated the effects of replacing grains with BT on growth of finishing lambs, finding variable effects of 20 and $40 \mathrm{~g} \mathrm{BT} / \mathrm{kg}$ DM on average daily gain (ADG) and feed conversion (RužićMuslić et al., 2009; Ahmed et al., 2015). Booyens et al. (2012) also indicated the possibility of altering the FA 
profile of meat from lambs by feeding different sources of fat. When supplemental fat replaces grains and byproducts the formulation of the entire diet should be considered. This is because replacing grain with saturated free FAs can result in increased energy intake simultaneous with reduced DM intake (DMI). Alternatively, increasing forage in diets with supplemented fat potentially leads to a forage effect whereby DMI would be increased while the added fat could also increase energy density of the diet (Weiss \& PinosRodríguez, 2009). Therefore, the purpose of the study was to evaluate the addition of BT to high-grain diets on growth, rumen fermentation, carcass characteristics and the chemical composition and FA profile of meat from lambs.

\section{Materials and Methods}

All procedures were reviewed and approved by the Academical Committee of Facultad de Agronomía y Veterinaria of Universidad Autónoma de San Luis Potosí, in compliance with Mexican laws enacted for the use of animals in experimentation (NOM-062-ZOO-1999).

Twenty-one five-month-old Rambouillet ram lambs weighing $28.8 \mathrm{~kg} \pm 2.8 \mathrm{~kg}$ were assigned randomly to one of the three experimental diets containing 0,20 and $40 \mathrm{~g} \mathrm{BT} / \mathrm{kg}$ DM. Diets (Table 1 ) were formulated according to NRC (1985) to meet the requirements for finishing lambs between four and seven months of age and weighing $30 \mathrm{~kg}$.

Lambs were housed in an open barn in individual cages $(0.8 \mathrm{~m} \times 1.2 \mathrm{~m})$ equipped with feeder and water trough. Lambs were fed twice a day ( $8 \mathrm{h00}$ and 16h00) and had free access to feed and fresh water for a 60-day period (15 days for adaptation to experimental diets and individual cages, and 45 days for experimental sampling). Feed samples offered and refused were collected weekly and composited. They were then dried in a forced air oven at $90^{\circ} \mathrm{C}$ for 48 hours to determine DM and subsequently ground to pass through a $1 \mathrm{~mm}$ screen (Thomas Wiley mill, Thomas Scientific LLC, Swedesboro, NJ, USA). Crude protein (CP), starch, ether extract (EE) and ash were determined according to procedures of the AOAC (2006). Neutral detergent fibre (NDF) was assayed with a heat stable amylase and expressed inclusive of residual ash (Mertens, 2002). Determination of acid detergent fibre (ADF) was by the method of Van Soest et al. (1991) with using an $\mathrm{AMKOM}_{200}$ (AMKOM Technology Co., Fairport, NT, USA). In vitro organic matter digestibility (IVOMD) was determined using the two-stage technique of Tilley and Terry (1963). The IVOMD values were used to predict digestible energy $(\mathrm{DE})(\mathrm{MJ} / \mathrm{kg})$ as:

$$
\mathrm{DE}(\mathrm{MJ} / \mathrm{kg})=0.27+0.04289(\mathrm{IVOMD}) \quad \text { (Fonnesbeck et al., 1984) }
$$

Digestible energy values were then converted to metabolizable energy (ME) using the formula:

$$
\mathrm{ME}(\mathrm{MJ} / \mathrm{kg})=0.8219 \mathrm{DE} \quad(\mathrm{NRC}, 2001) \text {. }
$$

Bodyweights were recorded before the morning feeding on days 1, 15, 30, and 45. Feed intake was measured daily as the difference between the amounts of feed offered and refused. Ad libitum intake was assured by offering $5 \%$ more feed than was previously consumed. Average daily gain was calculated from the changes in bodyweight. Feed conversion was calculated by dividing DMI by ADG. Metabolizable energy intake was calculated with DMI x ME energy in feed.

On day 45 , three hours after the morning feeding, rumen samples were obtained via an oesophagus tube, and $\mathrm{pH}$ was determined immediately $(\mathrm{pH}$ Testr37®, Double Junction, Waterproof, USA). A subsample $(10 \mathrm{~mL})$ of filtered ruminal fluid was mixed with $1 \mathrm{~mL}$ of $25 \%$ metaphosphoric acid and frozen at $-20{ }^{\circ} \mathrm{C}$. For volatile fatty acid (VFA) quantification, ruminal fluids were centrifuged at $9500 \mathrm{~g}$ for $15 \mathrm{~min}$, and $1 \mu \mathrm{L}$ of supernatant was injected into a gas chromatograph (HP® 6890 Agilent, USA) according to Erwin et al. (1961). The concentration of ammonia-nitrogen $\left(\mathrm{NH}_{3}-\mathrm{N}\right)$ was determined using $20 \mu \mathrm{L}$ of supernatant plus phenol and sodium hypochlorite incubated at $38{ }^{\circ} \mathrm{C}$ for $30 \mathrm{~min}$ (McCullough, 1967). Absorbance (Spectrophotometer UV/VIS Agilent ${ }^{\circledR} 8453$, USA) was recorded at $540 \mathrm{~nm}$.

On day 46, after a 24-hour fast, lambs were stunned with a captive bolt device and slaughtered at Facultad de Agronomía y Veterinaria abattoir, complying with the applicable Mexican regulation (NOM-033ZAG/ZOO-2014). Carcass weight was recorded immediately, and dressing percentage was calculated by dividing carcass weight by final bodyweight and multiplying by 100 (Zimmerman et al., 2008). The degree of fatness and carcass conformation of lambs were classified according to Mexican scale (NMX-FF-106-SCFI2006). Carcass and leg length, width of buttock and thorax, and area at 12th rib were measured as described by Ruiz de Huidobro et al. (2005).

On the day of slaughter, the Longissimus thoracis et lumborum (LTL) of the left side between the tenth thoracic vertebra and the sixth lumbar vertebra was dissected, vacuum packed and frozen at $-20{ }^{\circ} \mathrm{C}$. On days 5 and 8 after slaughter, meat quality parameters (area $\mathrm{pH}$, compression, colour and chemical composition) were determined. To calculate, LTL area at the 12th rib, the circumference of the chop eye was 
drawn on acetate and its area was obtained by planimetry. Immediately after thawing the LTL meat sample, the $\mathrm{pH}$ was measured ( $\mathrm{pH}$ meter, Thermo-Orion 410Aplus, Torrington, CT, USA). A compression test (Lepetit \& Buffiere, 1993) was carried out with a texturometer applying up to $20 \%$ strain at a speed of 50 $\mathrm{mm} / \mathrm{min}$ (Instron universal texturometer, Instron 3365, Grove City, Pennsylvania, USA). Luminosity (Hunter $L^{*}$ value), redness (Hunter $a^{*}$ value), and yellowness (Hunter $b^{*}$ value) were read with a colorimeter (Konica Minolta On Colour CM-2500d Online, Osaka, Japan). Moisture content of the LTL samples was determined by freeze drying and their fat content was determined using a Goldfisch fat extractor (Labconco Corp., Kansas City, MO, USA). Quantities of crude protein and ash in LTL samples were determined following (AOAC, 2006) and expressed as percentage of sample weight.

Table 1 Ingredients and chemical composition of isocaloric and isonitrogenous diets used to test effects of added beef tallow

\begin{tabular}{|c|c|c|c|}
\hline & \multicolumn{3}{|c|}{ Dietary treatments } \\
\hline & 0 & 20 & 40 \\
\hline \multicolumn{4}{|l|}{ Ingredient (g/kg DM) } \\
\hline Corn, whole grain & 660 & 520 & 380 \\
\hline Soybean meal $48 \% \mathrm{CP}$ & 120 & 100 & 90 \\
\hline Cane molasses & 80 & 80 & 80 \\
\hline Alfalfa hay & 50 & 70 & 90 \\
\hline Wheat middling & & 120 & 230 \\
\hline Vitamin and mineral premix ${ }^{1}$ & 90 & 90 & 90 \\
\hline Beef tallow & & 20 & 40 \\
\hline \multicolumn{4}{|l|}{ Chemical composition } \\
\hline DM (g/kg) & 880 & 888 & 895 \\
\hline $\mathrm{CP}(\mathrm{g} / \mathrm{kg} \mathrm{DM})$ & 141 & 141 & 144 \\
\hline NDF (g/kg DM) & 95 & 132 & 167 \\
\hline ADF (g/kg DM) & 46 & 61 & 76 \\
\hline Starch (g/DM) & 327 & 283 & 239 \\
\hline Ash & 122 & 127 & 132 \\
\hline IVOMD (g/kg DM) & 766 & 775 & 778 \\
\hline $\mathrm{ME}(\mathrm{MJ} / \mathrm{kg} \mathrm{DM})$ & 12.1 & 12.3 & 12.4 \\
\hline $\mathrm{EE}(\mathrm{g} / \mathrm{kg})$ & 30 & 46 & 62 \\
\hline \multicolumn{4}{|l|}{ Fatty acids (g/100 g fat) } \\
\hline C12:0 Lauric acid & 0.1 & 0.7 & 1.9 \\
\hline C14:0 Myristic acid & 1.5 & 2.5 & 3.7 \\
\hline C16:0 Palmitic acid & 8.6 & 20.8 & 26.1 \\
\hline C18:0 Stearic acid & 4.8 & 8.5 & 15.6 \\
\hline C18:1 n-9 Oleic acid & 40.5 & 35.4 & 29.4 \\
\hline C18:2 n-6 Linoleic acid & 44.4 & 29.6 & 20.5 \\
\hline C18:3 n-3 Linolenic acid & 0.1 & 2.5 & 2.8 \\
\hline Saturated fatty acids (SFA) & 15.0 & 32.5 & 47.3 \\
\hline Unsaturated fatty acids (UFA) & 85.0 & 67.5 & 52.7 \\
\hline
\end{tabular}

DM: dry matter, CP: crude protein (Nx6.25), NDF: neutral detergent fibre, ADF: acid detergent fibre, IVOMD: in vitro organic matter digestibility; ME: metabolizable energy, EE: ether extract; SFA: ( $\Sigma$ C12:0, C14:0, C16:0, C17:0, C18:0); UFA: ( 2 C18:1 n-9, C18:2 n-6; C18:3 n-6)

${ }^{1} \mathrm{Ca}: 180$ g; NaCl: 180 g; S: 5 g; K: 5.6 g; Mg: 8 g; Zn: 50 g; Fe: 20 g; I: 0.5 g; Mn: 36 g; Co: 90 mg; Se: 90 mg; Vit. A: 3000 MIU; Vit. $D_{3}: 750$ MUI; Vit. E: 25 MUI 
The FA profiles of the diets and LTL samples determined after extraction with chloroform-methanol 2: $1(\mathrm{v} / \mathrm{v})$ and the esterified samples were analysed using by a gas chromatograph (Agilent Technologies, Santa Clara, California, USA) following Berdeaux (1999). Individual FA peaks were identified by comparison with known reference methyl esters (Supelco 37 Component FAME Mix, 47885-U, Sigma-Aldrich Co.). All FA values were expressed as a weight percentage of total FAs. In LTL samples, myoglobin, cathepsin B and cathepsin B+L concentrations were quantified as proposed by Trout (1990) and Etherington \& Wardale (1982).

The experimental design was a split plot that resulted from random assignment of seven lambs to each of the three diet treatments and repeated measurements that were collected over time. Data were analysed with a MIXED procedure using SAS release 9.1.3 (SAS Institute, Inc., Cary, North Carolina, USA) with the fixed treatment effects of BT level in the diet (two degrees of freedom (df)), and residual (lambs within treatment, $18 \mathrm{df}$ ) as the whole plot. The subplot consisted of time (repeated, $2 \mathrm{df}$ ) and interaction time*treatment which were included in the model with the AR(1) covariance structure. Polynomial contrasts were used to test the linear or quadratic effects of BT dietary level on the dependent variables. In addition, Tukey's test was used to detect differences between means. For those traits which were recorded at only one point in time, the model was reduced to contain only the whole plot. Categorical data (muscle conformation, fatness degree and perirenal fat) were analysed as a completely randomized design. The CATMOD procedure of SAS release 9.1.3 (SAS Institute, Inc., Cary, North Carolina, USA) was employed with the response functions considered as cumulative logits. The model included BT levels (treatments) in the diet (fixed, two df) and individual carcass as the experimental unit (residual $18 \mathrm{df}$ ). A probability of less than 0.05 was considered a statistically significant difference.

\section{Results and Discussion}

As expected, as additional BT was included in the diet, the EE and saturated fatty acid (SFA) contents, mainly $\mathrm{C} 16: 0$ and $\mathrm{C} 18: 0$, of the diet also increased and the contents of the unsaturated fatty acids (UFA) C18:1 n-9 and C18:2 n-6 decreased (Table 1). Perhaps because the diets were formulated to be isocaloric, lambs fed 0,20 , and $40 \mathrm{~g} \mathrm{BT} / \mathrm{kg}$ DM had similar final BW, total gain, ADG, DMI and feed conversion, and ruminal fermentation characteristics ( $\mathrm{pH}$ values, VFA molar proportion and ammonia $\mathrm{N}$ concentration). However, daily ME intake increased linearly $(P<0.05)$ as the BT level in the diet increased. Carcass classification, carcass weight and length, muscle conformation, leg length, width of buttock and thorax and area of the longissimus muscle at 12th rib were not affected by dietary level of BT. Carcass dressing, fatness degree and dorsal fat at the 12th rib increased linearly $(P<0.05)$ as BT level in the diet increased (Table 2). In agreement with the current results, previous studies using grain-based diets and BT at $40 \mathrm{~g} / \mathrm{kg} \mathrm{DM}$ have shown that the added fat did not affect growth performance and ruminal fermentation in finishing beef cattle (Guerrero et al., 2016; Lopez et al., 2016). Moreover, in finishing lambs, saturated beef tallow (30 g/kg DM) has been shown not to affect DMI (Booyens et al., 2013). Steers fed diets based on steam-flaked corn and supplemented with 0 and $40 \mathrm{~g} \mathrm{BT} / \mathrm{kg} \mathrm{DM}$ also had similar rumen pH values, VFA molar proportion and ammonia $\mathrm{N}$ concentrations (Montgomery et al., 2008). Thus, supplemental BT might not have influenced rumen fermentation characteristics of lambs and beef cattle, although it is uncertain if the same thing happens in dairy cows which are provided a diet that is high in C18 vegetable fats which reduce the digestibility of fibre (Palmquist \& Jenkins, 2017).

To the authors' knowledge, this is the first study to show that lambs fed isocaloric diets that were augmented with BT and concurrently with fibre had higher daily ME intake than lambs fed an unaugmented control diet. In dairy cows, Weiss \& Pinos-Rodríguez (2009) found that replacing corn grain with saturated free FAs was correlated with an increase in energy intake with that additional energy being mostly directed to body reserves. In growing lambs, an incremental increase in fat thickness at the 12th rib was noted with a diet that included $40 \mathrm{~g} \mathrm{BT} / \mathrm{kg}$ DM (Ahmed et al., 2015). Taken together, these studies suggest that including BT in the diet leads to an increase in energy intake, which probably enables available energy to be directed mostly to increased fat deposition with consequent increases in carcass dressing and carcass conformation (Table 2). 
Table 2 Means of growth performance, ruminal fermentation and carcass characteristics of finishing lambs fed diets with beef tallow

\begin{tabular}{|c|c|c|c|c|}
\hline & \multicolumn{3}{|c|}{ Dietary treatment - amount of beef tallow (g/kg DM) } & \multirow[b]{2}{*}{ SEM } \\
\hline & 0 & 20 & 40 & \\
\hline \multicolumn{5}{|l|}{ Growth performance } \\
\hline Initial BW (kg) & 28.9 & 29.0 & 28.5 & 0.57 \\
\hline Final BW (kg) & 44.0 & 44.1 & 44.3 & 1.08 \\
\hline Total gain (kg) & 15.1 & 15.1 & 15.8 & 0.81 \\
\hline ADG $(g)$ & 335.5 & 335.5 & 351.1 & 9.96 \\
\hline DMI $(g / d)$ & 999.4 & 1050.1 & 1060.7 & 22.91 \\
\hline ME intake $(M J d)^{L}$ & $12.1^{b}$ & $12.9^{\mathrm{a}}$ & $13.1^{\mathrm{a}}$ & 0.07 \\
\hline DMI/ADG & 2.98 & 3.12 & 3.02 & 0.39 \\
\hline \multicolumn{5}{|l|}{ Ruminal fermentation } \\
\hline $\mathrm{pH}$ & 5.81 & 5.90 & 5.95 & 0.10 \\
\hline Ammonia N (mg/L) & 142.1 & 138.9 & 145.0 & 7.89 \\
\hline Total VFA (mmol/L) & 91.3 & 92.9 & 92.8 & 3.77 \\
\hline Acetate (mol/100 mol) & 46.2 & 47.4 & 47.6 & 3.52 \\
\hline Propionate (mol/100 mol) & 37.0 & 36.3 & 35.0 & 2.01 \\
\hline Butyrate $(\mathrm{mol} / 100 \mathrm{~mol})$ & 16.8 & 16.3 & 17.4 & 1.84 \\
\hline Acetate: propionate ratio & 1.24 & 1.30 & 1.36 & 0.11 \\
\hline \multicolumn{5}{|l|}{ Carcass characteristics } \\
\hline Carcass weight (kg) & 21.2 & 22.9 & 23.0 & 0.51 \\
\hline Carcass dressing (\%) ${ }^{\mathrm{L}}$ & $48.2^{b}$ & $51.9^{\mathrm{a}}$ & $51.9^{a}$ & 0.71 \\
\hline Carcass length (cm) & 67.8 & 66.4 & 67.9 & 0.48 \\
\hline Carcass clasification $^{1}$ & 3.5 & 3.5 & 3.6 & 0.11 \\
\hline Muscle conformation $^{2}$ & 3.4 & 3.6 & 3.6 & 0.62 \\
\hline Fatness degree $\mathrm{C}^{3 \mathrm{~L}}$ & $3.4^{\mathrm{b}}$ & $4.1^{\mathrm{a}}$ & $4.2^{\mathrm{a}}$ & 0.38 \\
\hline Dorsal fat at 12 th rib $(\mathrm{mm})^{\mathrm{L}}$ & $1.1^{\mathrm{b}}$ & $1.4^{\mathrm{a}}$ & $1.5^{\mathrm{a}}$ & 0.12 \\
\hline Leg length $(\mathrm{cm})$ & 44.1 & 43.2 & 43.8 & 0.51 \\
\hline Width of buttock (cm) & 19.0 & 19.2 & 19.4 & 0.41 \\
\hline Width of thorax (cm) & 14.4 & 15.0 & 14.6 & 0.28 \\
\hline Area at 12th rib $\left(\mathrm{cm}^{2}\right)$ & 20.0 & 20.3 & 20.9 & 0.47 \\
\hline
\end{tabular}

Except for intramuscular fat, none of the characteristics of the meat measured on either day 5 or day 8 post-mortem were affected by the addition of BT to the diet. The absence of a significant relationship between BT and meat colour may resulted from the lack of differences in $\mathrm{pH}$ as indicated by Fiorentini et al. (2015). Intramuscular fat content increased linearly $(P<0.05)$ as BT level in the diet increased (Table 3 ). Although Wood et al. (2008) found a correlation between muscle lipid content (intramuscular fat) and meat tenderness, they also did not observe an effect of dietary BT on meat texture or colour. The inconsistent effects of dietary BT on meat characteristics were noted by Nelson et al. (2008).

Despite the differences in the FA profiles of the current experimental diets, none of the individual FAs in the meat was affected by the dietary BT (Table 4). This was not observed in another study, where inclusion of saturated tallow (30 $\mathrm{g} / \mathrm{kg}$ DM) resulted in higher lamb muscle content of palmitoleic acid (C16:1c9) and monounsaturated fatty acids (MUFAs) (Booyens et al., 2012). One explanation for the lack of 
effect of dietary BT on fatty meat FA profile might be that FAs originating from BT are in the free form and not bound within triacyl glycerol molecules (Siebrits et al., 2009).

Table 3 Means of carcass and Longissimus dorsi characteristics of finishing lambs at five and eight days post-mortem

\begin{tabular}{|c|c|c|c|c|}
\hline \multirow{2}{*}{ Meat characteristic } & \multicolumn{3}{|c|}{ Dietary treatment - amount of beef tallow (g/kg DM) } & \multirow[b]{2}{*}{ SEM } \\
\hline & 0 & 20 & 40 & \\
\hline \multicolumn{5}{|l|}{5 days post-mortem } \\
\hline Texture $\left(\mathrm{N} / \mathrm{cm}^{2}\right)^{1}$ & 8.8 & 8.7 & 8.9 & 0.93 \\
\hline Lightness index $\left(L^{*}\right)$ & 39.8 & 40.3 & 40.4 & 1.01 \\
\hline Redness index $\left(\mathrm{a}^{\star}\right)$ & 7.5 & 7.8 & 8.1 & 0.71 \\
\hline Yellowness index $\left(b^{\star}\right)$ & 11.7 & 12.0 & 11.3 & 0.95 \\
\hline $\mathrm{pH}$ & 5.6 & 5.7 & 5.7 & 0.12 \\
\hline Cathepsin $\mathrm{B}^{2}$ & 266 & 275 & 269 & 17.31 \\
\hline Cathepsin $B+L^{2}$ & 305 & 314 & 325 & 18.90 \\
\hline Myoglobin, mg/g & 0.28 & 0.29 & 0.25 & 0.02 \\
\hline Protein Lowry (mg/mL) & 0.38 & 0.39 & 0.42 & 0.10 \\
\hline Moisture (g/kg) & 784 & 779 & 781 & 9.41 \\
\hline Crude protein $(\mathrm{g} / \mathrm{kg})$ & 180 & 176 & 178 & 5.05 \\
\hline Fat $(g / k g)^{L}$ & $47.1^{\mathrm{b}}$ & $49.0^{\mathrm{ab}}$ & $49.8^{\mathrm{a}}$ & 0.95 \\
\hline Ash (g/kg) & 36.4 & 34.9 & 35.6 & 2.11 \\
\hline \multicolumn{5}{|l|}{8 days post-mortem } \\
\hline Texture $\left(\mathrm{N} / \mathrm{cm}^{2}\right)^{1}$ & 1.9 & 1.5 & 1.6 & 0.43 \\
\hline Lightness index $\left(L^{*}\right)$ & 42.5 & 43.9 & 43.4 & 1.02 \\
\hline Redness index $\left(a^{\star}\right)$ & 7.0 & 6.8 & 6.5 & 0.83 \\
\hline Yellowness index $\left(b^{\star}\right)$ & 12.1 & 12.0 & 12.0 & 1.02 \\
\hline $\mathrm{pH}$ & 5.7 & 5.5 & 5.5 & 0.11 \\
\hline Cathepsin $\mathrm{B}^{2}$ & 321 & 322 & 324 & 16.31 \\
\hline Cathepsin $B+L^{2}$ & 344 & 349 & 352 & 15.60 \\
\hline Myoglobin (mg/g) & 0.31 & 0.30 & 0.28 & 0.02 \\
\hline Protein Lowry (mg/mL) & 0.36 & 0.39 & 0.40 & 0.22 \\
\hline Moisture $(\mathrm{g} / \mathrm{kg})$ & 784 & 769 & 777 & 9.41 \\
\hline Crude protein $(\mathrm{g} / \mathrm{kg})$ & 180 & 172 & 175 & 5.89 \\
\hline Fat $(g / k g)^{L}$ & $47.0^{\mathrm{b}}$ & $48.3^{\mathrm{ab}}$ & $49.7^{a}$ & 0.92 \\
\hline Ash (g/kg) & 36.4 & 34.9 & 35.6 & 2.61 \\
\hline
\end{tabular}

\footnotetext{
${ }^{1}$ Compression test at $20 \%$ of total compression

${ }^{2}$ Expressed as specific activity in nmol of NMec (amino-methylcoumarin) released per $\mathrm{min} / \mathrm{mg}$ protein

${ }^{\mathrm{a}, \mathrm{b}}$ Row means with different superscripts differ at $P<0.05{ }^{\mathrm{L}}{ }^{\mathrm{L}}$ and ${ }^{\mathrm{Q}}$ denote the significant $(P<0.05)$ linear and quadratic effects, respectively
} 
Table 4 Effect of tallow supplementation on fatty acid profile in Longissimus dorsi of finishing lambs

\begin{tabular}{|c|c|c|c|c|}
\hline \multirow{2}{*}{ Fatty acid (g/100 g) } & \multicolumn{3}{|c|}{ Dietary treatment - amount of beef tallow ( $\mathrm{g} / \mathrm{kg} \mathrm{DM}$ ) } & \multirow[b]{2}{*}{ SEM } \\
\hline & 0 & 20 & 40 & \\
\hline C10:0, Capric acid & 0.27 & 0.23 & 0.25 & 0.03 \\
\hline C12:0, Lauric acid & 0.29 & 0.25 & 0.23 & 0.04 \\
\hline C14:0, Myristic acid & 4.71 & 4.89 & 4.91 & 0.06 \\
\hline C15:0, Pentadecanoic acid & 0.85 & 0.64 & 0.65 & 0.05 \\
\hline C16:0, Palmitic acid & 27.20 & 27.11 & 26.40 & 0.61 \\
\hline C16:1, Palmitoleic acid & 2.35 & 2.01 & 2.09 & 0.29 \\
\hline C17:0, Margaric acid & 1.22 & 1.12 & 1.11 & 0.17 \\
\hline C17:1 c9 fatty acid & 0.79 & 0.84 & 0.82 & 0.09 \\
\hline C18:0, Stearic acid & 16.90 & 17.30 & 18.90 & 1.03 \\
\hline C18:1 t9, Elaidic acid & 1.94 & 2.28 & 1.99 & 0.79 \\
\hline C18:1 c9, Oleic acid & 37.90 & 37.80 & 37.20 & 1.59 \\
\hline C18:2 n-6, Linoleic acid & 4.15 & 3.92 & 3.93 & 0.99 \\
\hline C18:3 n-3, Linolenic acid & 0.42 & 0.46 & 0.42 & 0.11 \\
\hline C18:2 CLA cis9-trans11, Conjugated linoleic acid & 0.45 & 0.51 & 0.49 & 0.09 \\
\hline C20:4 n-6, Arachidonic acid & 0.56 & 0.65 & 0.61 & 0.09 \\
\hline SFA & 51.40 & 51.50 & 52.40 & 1.99 \\
\hline MUFA & 42.90 & 42.90 & 42.10 & 2.76 \\
\hline PUFA & 5.58 & 5.54 & 5.45 & 1.28 \\
\hline
\end{tabular}

\section{Conclusion}

Inclusion of BT (40 g BT/ $\mathrm{kg} \mathrm{DM}$ ) as energy source, fibre supplement and grain replacement in finishing lamb diets correlated linearly with an increase in energy intake, carcass dressing and fatness, and muscle fat content, while DMI, growth performance and rumen fermentation were unaffected. In addition, BT does not have noticeable effects on texture, meat colour or FA profile. Therefore, dietary BT for finished lambs may be an option to minimize grains in diets without changing growth performance or meat traits.

\section{Acknowledgments}

PRODEP-SEP are gratefully acknowledged for their financial support though the NPTC (511-6/18-9245 PTC-890) and postdoctoral (511-6/18-9811) projects.

\section{Authors' Contributions}

SLA and ADC conducted the experiment; JMPR conceived, designed and supervised the research; IADM evaluated the carcasses; JGV and HLR analysed the feed and meat samples.

\section{Conflict of Interest Declaration}

The authors have declared that no competing interests exist

\section{References}

Ahmed, S., Khatun, J., Islam, M., Khan, M.I., Mahmud, S.M.N. Noman, A.A. \& Islam, Z., 2015. Effect of beef tallow on growth performance, carcass characteristics, meat composition, and lipid profile of growing lambs. J. Adv. Vet. Anim. Res. 2, 355-361.

AOAC, 2006. Official methods of analysis (18th ed). Association of Official Analytical Chemists, Inc., Washington, DC, USA.

Berdeaux, O., Márquez, G.R. \& Dobarganes, C., 1999. Selection of methylation procedures for quantitation of shortchain glycerol-bound compounds formed during thermoxidation. J. Chromatogr. 2, 171-181. 
Booyens, K.E., Einkamerer, O.B., Hugo, A., Van der Merwe, H.J., Slippers, S.C. \& Fair, M.D., 2012. Fatty acid composition and oxidative stability of lambs' meat as affected by a bioflavonoid antioxidant and fat source. S. Afr. J. Anim. Sci. 42(Suppl. 1), 483-487.

Booyens, K.E., Einkamerer, O.B., Van der Merwe, H.J., Hugo, A., Slippers, S.C. \& Fair, M.D., 2013. The effect of dietary lipid saturation and antioxidant source on the nutrient digestibility of lamb finishing diets. S. Afr. J. Anim. Sci. 43(Suppl. 1), S23-S26.

Erwin, E.S., Marco, G.J. \& Emery, E., 1961. Volatile fatty acid analysis of blood and rumen fluid by gas chromatography. J. Dairy Sci. 44, 1798-1776.

Etherington, D.J. \& Wardale, R.J., 1982. The mononuclear cell population in rat leg muscle: its contribution to the lysosomal enzyme activities of whole muscle extracts. J. Cell Sci. 58, 139-148.

Fiorentini, G., Lage, J.F., Carvalho, I.P.C., Messana, J.D., Canesin, R.C., Reis, R.A. \& Berchielli, T.T., 2015. Lipid sources with different fatty acid profile alters the fatty acid profile and quality of beef from confined Nellore steers. Asian-Australas. J. Anim. Sci. 28, 976-986.

Fonnesbeck, P.V., Clark, D.H., Garret, W.N. \& Speth, C.F., 1984. Predicting energy utilization from alfalfa hay from the western region. Proc. Am. Soc. Anim. Sci. 35, 305-308.

Guerrero, A., Muela, E., Valero, M.V., Prado, I.N., Campo, M.M., Olleta, J.L., Catalán, O. \& Sañudo, C., 2016. Effect of the type of dietary fat when added as an energy source on animal performance, carcass characteristics and meat quality of intensively reared Friesian steers. Anim. Prod. Sci. 56, 1144-1151.

Howes, N.L., Bekhit, A.E.A., Burrit, D.J. \& Campbell, A.W., 2014. Opportunities and implications of pasture-based lamb fattening to enhance the long-chain fatty acid composition in meat. Compr. Rev. Food Sci. Food Saf. 14, 22-36.

Lepetit, J. \& Buffiere, C., 1993. Comparaison de deux méthodes mécaniques de mesure de la résistance myofibrillaire de la viande crue. Viandes et Produit Carnés. Ind. Alim. Agric. 14, 39-42 (in French).

Lopez, R., Pulsipher, G.D., Guerra-Liera, J.E., Soto-Navarro, S.A., Balstad, L.A., Petersen, M.K., Dhuyvetter, D.V., Brown, M.S. \& Krehbiel, C.R., 2016. Effects of fat and/or methionine hydroxy analog added to a molasses-ureabased supplement on ruminal and postruminal digestion and duodenal flow of nutrients in beef steers consuming low-quality lovegrass hay. J. Anim. Sci. 94, 2485-2496.

McCullogh, H., 1967. The determination of ammonia in whole blood by direct colorimetric method. Clin. Chem. Acta. 17, 297-304.

Mertens, D.R., 2002. Gravimetric determination of amylase-treated neutral detergent fibre in feeds with refluxing beakers or crucibles: Collaborative study. J. Assoc. Off. Assoc. Chem. Int. 85, 1217-1240.

Montgomery, S.P., Drouillard, J.S., Nagaraja, T.G., Titgemeyer, E.C. \& Sindt, J.J., 2008. Effects of supplemental fat source on nutrient digestion and ruminal fermentation in steers. J. Anim. Sci. 86, 640-650.

NRC, 1985. Nutrient requirements of sheep (6th ed.). National Academy Press. Washington, D.C., USA.

NRC, 2001. Nutrient requirements of dairy cattle (7th revised ed.). National Academy Press. Washington DC, USA.

Nelson, M.L., Busboom, J.R., Ross, C.F. \& O’Fallon, J.V., 2008. Effects of supplemental fat on growth performance and quality of beef from steers fed corn finishing diets. J. Anim. Sci. 86, 936-948.

NMX-FF-106-SCFI-2006. Productos pecuarios. Clasificación de carne ovina en canal. Diario Oficial de la Federación, Julio 4, México. (in Spanish).

NOM-033-SAG/ZOO-2014, Norma Oficial Mexicana, Métodos para dar muerte a los animales domésticos y silvestres. Diario Oficial de la Federación. Agosto 28, México (in Spanish).

NOM-062-ZOO-1999. Especificaciones técnicas para la producción, cuidado y uso de los animales de laboratorio. Diario Oficial de la Federación. Diciembre6, México (in Spanish).

Palmquist, D.L. \& Jenkins, T.C., 2017. A 100-year review: fat feeding of dairy cows. J. Dairy Sci. 100, 10061-10077.

Pinos, R.J.M., 2010. Uso de dietas altas en granos en la alimentación de ovinos para carne. En: Curso Avances de Nutrición Ovina III Facultad de Medicina Veterinaria y Zootecnia. Universidad Autónoma del Estado de México. El Cerrillo, Estado de México, septiembre 23, México (in spanish).

Ruiz de Huidobro, F., Miguel, E., Cañeque, V. \& Velasco, S., 2005. Conformación, engrasamiento y sistemas de clasificación de la canal ovina. In: V. Cañeque, \& C. Sañudo (ed). Estandarización las Metodologías para Evaluar la Calidad del Producto (animal vivo, canal, carne y grasa) en los Rumiantes. Monografías. INIA: serie ganadera 3, 143-178. Madrid, España (in Spanish).

Ružić-Muslić, D., Petrović, M.P. \& Bijelić, Z., 2009. The effect of beef tallow in lamb nutrition on fattening and carcass characteristics. Biotech. Anim. Husbandry 25, 431-438.

Scollan, N., Enser, M., Gulati, S., Richardson, I. \& Wood, J., 2007. Effects of including a ruminally protected lipid supplement in the diet on the fatty acid composition of beef muscle. Br. J. Nutr. 90, 709-716.

Siebrits, F.K., Makgekgenene, A. \& Hugo, A., 2009. Effect of saponified high fat sunflower oilcake and lipoic acid on fat quality of lambs. S. Afr. J. Anim. Sci. 39 (Suppl.1), 29-32.

Tilley, J.M.A. \& Terry, R.A., 1963. A two-stage technique for the in vitro digestion of forage crops. J. Br. Grassl. Soc. 18, 104-111.

Trout, G.R., 1990. The rate of metmyoglobin formation in beef, pork, and turkey meat as influenced by $\mathrm{pH}$, sodium chloride, and sodium tripolyphosphate. Meat Sci. 28, 203-210.

Van Cleef, F. de O.S., Ezequiel, J.M.B., D'Aurea, A.P., Almeida, M.T.C., Perez, H.L. \& Van Cleef, E.H.C.B., 2016. Feeding behavior, nutrient digestibility, feedlot performance, carcass traits, and meat characteristics of crossbred lambs fed high levels of yellow grease or soybean oil. Small Rumin. Res. 137, 151-156.

Van Soest, P.J., Robertson, J.B. \& Lewis, B.A., 1991. Methods for dietary fibre, neutral detergent fibre and non-starch polysaccharides in relation to animal nutrition. J. Dairy Sci. 74, 3583-3597. 
Weiss, W.P. \& Pinos Rodríguez, J.M., 2009. Production response of dairy cows when fed supplemental fat in low- and high-forage diets. J. Dairy Sci. 92, 6144-6155.

Weld, K.A. \& Armentano, L.E., 2017. The effect of adding fat to diets of lactating dairy cows on total-tract neutral detergent fiber digestibility: A meta-analysis. J. Dairy Sci. 100, 1766-1779.

Wood, J.D., Enser, M., Fisher, A.V., Nute, G.R., Sheard, P.R, Richardson, R.I., Hughes, S.I. \& Whittington, F.M., 2008. Fat deposition, fatty acid composition and meat quality: A review. Meat Sci. 78, 343-358.

Zimmerman, M., Domingo, E. \& Lanari, M.R., 2008. Carcass characteristics of Neuquén Criollo kids in Patagonia region, Argentina. Meat Sci. 79, 453-457. 